Section Editor

John J. Millichap, MD
Teaching NeuroImages:

\section{Artery of Percheron thrombosis causing selective downgaze palsy}

Matthew Sechler, MD

Jasmeet Singh, MD

Nada El Husseini, MD, MHSc

Correspondence to

Dr. El Husseini:

nelhusse@wakehealth.edu
Download teaching slides: Neurology.org

Figure 1 Cardinal positions of gaze at presentation demonstrate the isolated downgaze palsy

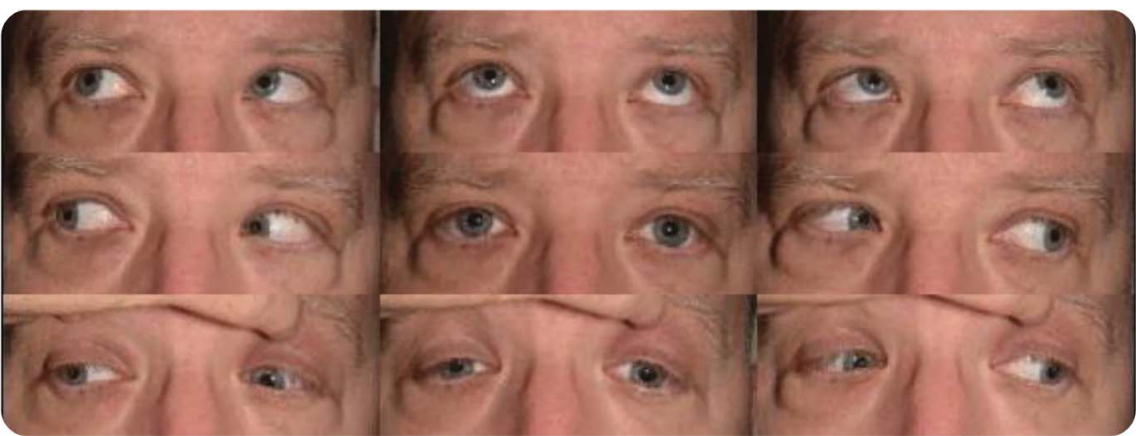

A 47-year-old man with migraines presented with sudden onset of vertical diplopia, dysarthria, right facial weakness, and downgaze palsy (figure 1). Brain MRI revealed ischemic strokes in the midbrain periaqueductal gray, bilateral thalamic-midbrain junction, and thalamus (figure 2, A-C). Gradient echo and T1 MRI showed hypointensity in the interpeduncular fossa (figure 2, D and E). No flow could be visualized in this structure on CT angiogram or catheter angiogram, demonstrating a thrombosed artery of Percheron (figure 2, F-H). Downgaze palsy, which improved 18 months later, may result from bilateral lesions of the mesencephalicdiencephalic junction involving the rostral interstitial nucleus of the medial longitudinal fasciculus. ${ }^{1,2}$

\section{AUTHOR CONTRIBUTIONS}

Dr. Sechler: study concept and design, acquisition of data, analysis and interpretation. Dr. Singh: acquisition of data, analysis and interpretation, critical revision of the manuscript for important intellectual content.
Dr. El Husseini: study concept and design, acquisition of data, analysis and interpretation, critical revision of the manuscript for important intellectual content, study supervision.

\section{STUDY FUNDING}

No targeted funding reported.

\section{DISCLOSURE}

The authors report no disclosures relevant to the manuscript. Go to Neurology.org for full disclosures.

\section{REFERENCES}

1. Green JP, Newman NJ, Winterkorn JS. Paralysis of downgaze in two patients with clinical-radiologic correlation. Arch Ophthalmol 1993;111:219-222.

2. Pierrot-Deseilligny $\mathrm{CH}$, Chain F, Gray F, Serdaru M, Escourolle R, Lhermitte F. Parinaud's syndrome: electro-oculographic and anatomical analyses of six vascular cases with deductions about vertical gaze organization in the premotor structures. Brain 1982;105: 667-696. 

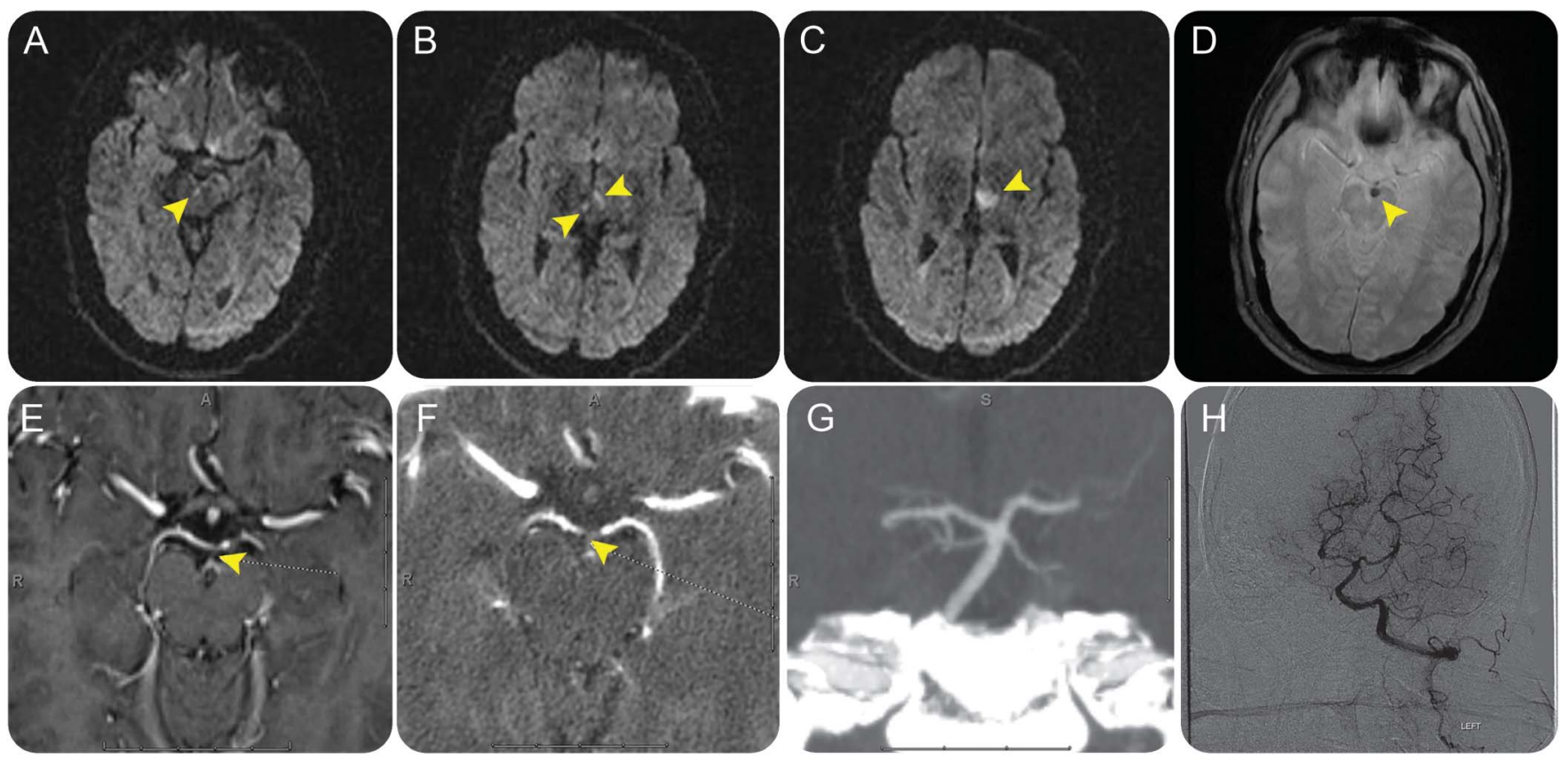

(A-C) MRI diffusion-weighted imaging shows restricted diffusion in the midbrain, thalamic-midbrain junction, and left thalamus. (D) Gradient echo MRI shows blooming artifact in the interpeduncular fossa concerning for a thrombus. (E) Contrasted T1 MRI shows filling defect in a posteriorly directed linear midline vascular structure. (F) CTA (axial) shows filling defect in the proximal artery of Percheron. (G) CTA (coronal) shows patent basilar apex with no aneurysm or vascular malformation. $(\mathrm{H})$ Catheter angiogram shows no flow in the midline vessel concerning for artery of Percheron thrombosis. 


\section{Neurology}

\section{Teaching NeuroImages: Artery of Percheron thrombosis causing selective downgaze palsy \\ Matthew Sechler, Jasmeet Singh and Nada El Husseini \\ Neurology 2017;89; e197-e198 \\ DOI 10.1212/WNL.0000000000004522}

This information is current as of October 16, 2017

\begin{tabular}{|c|c|}
\hline $\begin{array}{l}\text { Updated Information \& } \\
\text { Services }\end{array}$ & $\begin{array}{l}\text { including high resolution figures, can be found at: } \\
\text { http://n.neurology.org/content/89/16/e197.full }\end{array}$ \\
\hline Supplementary Material & $\begin{array}{l}\text { Supplementary material can be found at: } \\
\text { http://n.neurology.org/content/suppl/2017/10/16/WNL.0000000000004 } \\
\text { 522.DC1 }\end{array}$ \\
\hline References & $\begin{array}{l}\text { This article cites } 2 \text { articles, } 0 \text { of which you can access for free at: } \\
\text { http://n.neurology.org/content/89/16/e197.full\#ref-list-1 }\end{array}$ \\
\hline Subspecialty Collections & $\begin{array}{l}\text { This article, along with others on similar topics, appears in the } \\
\text { following collection(s): } \\
\text { All Cerebrovascular disease/Stroke } \\
\text { http://n.neurology.org/cgi/collection/all_cerebrovascular_disease_strok } \\
\text { e } \\
\text { DWI } \\
\text { http://n.neurology.org/cgi/collection/dwi } \\
\text { Infarction } \\
\text { http://n.neurology.org/cgi/collection/infarction } \\
\text { MRI } \\
\text { http://n.neurology.org/cgi/collection/mri }\end{array}$ \\
\hline Permissions \& Licensing & $\begin{array}{l}\text { Information about reproducing this article in parts (figures,tables) or in } \\
\text { its entirety can be found online at: } \\
\text { http://www.neurology.org/about/about_the_journal\#permissions }\end{array}$ \\
\hline Reprints & $\begin{array}{l}\text { Information about ordering reprints can be found online: } \\
\text { http://n.neurology.org/subscribers/advertise }\end{array}$ \\
\hline
\end{tabular}

Updated Information \&

Supplementary Material

\section{References}

Subspecialty Collections

Neurology ${ }^{\circledR}$ is the official journal of the American Academy of Neurology. Published continuously since 1951, it is now a weekly with 48 issues per year. Copyright @ 2017 American Academy of Neurology. All rights reserved. Print ISSN: 0028-3878. Online ISSN: 1526-632X.

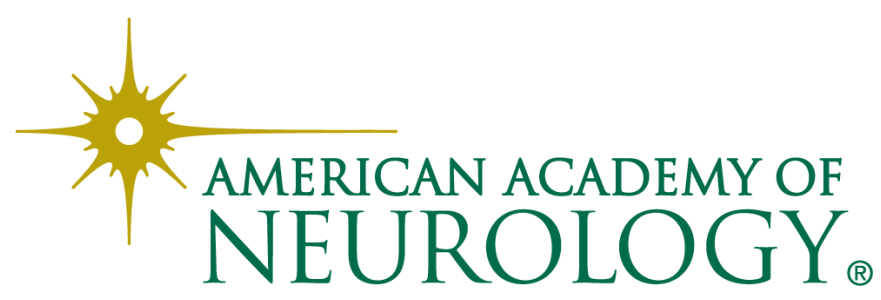

